\title{
Can the Political Ambition of Young Women Be Increased? Evidence from U.S. High School Students *
}

\author{
Joshua Kalla $^{\dagger}$ \\ Yale University
}

\author{
Ethan Porter \\ George Washington University
}

\begin{abstract}
The under-representation of women in American politics can likely be explained, at least in part, by women's comparatively lower levels of political ambition. We analyze a co-ed, religious program for high school students in which participants lobby their Members of Congress and receive political skills training. By leveraging longitudinal survey data about the participants and a difference-in-differences design, we find that the program successfully increased the political ambition of its female participants. To the best of our knowledge, we offer the first quasi-experimental evidence demonstrating a possible means of increasing the political ambition of high school-aged American women. Our results demonstrate that female political ambition can be increased without relying on programs that explicitly focus on gender and ambition.
\end{abstract}

*We thank the Religious Action Center of Reform Judaism, especially Sara Barrack, Sophie Kaplan and Shira Zemel for implementation. We thank Danny Hayes, Jennifer Lawless, John Sides, Chris Warshaw and Ronit Zemel for their comments. Casey Danoff provided excellent research assistance. This research was approved by the George Washington University Institutional Review Board, IRB \#80459. All errors are our responsibility alone.

${ }^{\dagger}$ Assistant Professor, Department of Political Science and Department of Statistics and Data Science; josh.kalla@yale.edu

${ }^{\ddagger}$ Assistant Professor, School of Media and Public Affairs and Department of Political Science; evporteregwu. edu 
The dearth of female candidates and office-holders in the United States is well-documented (e.g., Carroll and Fox, 2018; Rosenbluth, Kalla, and Teele, 2015). A broad swath of political activists and organizations, including long-standing groups such as EMILY's List, as well as newer organizations such as Emerge America, She Should Run and Higher Heights, focus on encouraging and electing female candidates (Epstein, 2018; Bernhard, Shames, and Teele, 2021). While many of these organizations lean Democratic, Republican efforts, such as the Susan B. Anthony List and Maggie's List, also exist (Miller, 2019). Despite their partisan differences, these organizations share a commitment to cultivating female political ambition in order to increase the supply of female candidates. They often do so in ways similar to the efforts studied by Karpowitz, Monson, and Preece (2017) and Karpowitz and Mendelberg (2018): By specifically targeting potential female candidates and by making overt reference to the need for greater female political ambition.

In this paper, we examine the effects of a political program for high school students on political ambition, paying special attention to the female participants. By the time they set foot on college campuses, young women express markedly lower levels of political ambition than men (Fox and Lawless, 2014; Lawless and Fox, 2014). An intervention targeted at high school women could thus be especially fruitful for reducing the gender gap in representation. However, unlike much of the existing research and political activism on female candidates and political ambition, the program we study here draws both male and female participants. The program we study, "L'Taken," (pronounced le-ta-ken) is administered by the Religious Action Center of Reform Judaism (known as the RAC), the political advocacy arm of the Union for Reform Judaism. Participants are high school students affiliated with Reform synagogues across the United States. The three-day program takes place six times a year in Washington, D.C., attracting hundreds of different participants each time. While in Washington, participants learn about policy issues important to the Reform Jewish movement, receive training in political 
advocacy, and lobby their Congressional representatives or those representatives' staff members on policy issues. The program is not focused on increasing the political ambition of female participants. Indeed, female participants are not told about the comparative lack of political ambition among young women and participants remain in mixed-gender settings throughout the program. But as we describe in greater detail below, existing research suggests it may be capable of enhancing political ambition nonetheless.

We are not the first researchers to investigate possible ways of increasing female political ambition. Foos and Gilardi (2020) report an experiment conducted on female university students, some of whom were randomly assigned to attend a professional workshop with female politicians. Ultimately, the researchers were unable to detect effects on a behavioral measure of political ambition. On the other hand, Preece (2016) describes treatments that narrowed the gender gap in interest in politics. Similarly, Karpowitz, Monson, and Preece (2017) conducted an experiment in partnership with a state Republican Party, in which messages sent by the state party chair that made explicit mention of the gender disparity increased the number of women elected to a party convention.

In contrast to this existing work, the L'Taken program does not explicitly discuss gender and ambition, nor does it separate participants into gender-specific programming. However, several components of L'Taken could plausibly increase the political ambition of its participants. The program provides civic skills training; it exposes participants to political role models, including same-gender role models; and it connects participants directly to their political representatives, potentially increasing their sense of efficacy. In sum, existing research offers reason to think that, even though L'Taken is not designed explicitly to enhance political ambition, it could do so nonetheless.

On the other hand, the program's differences with the efforts studied by Karpowitz, Monson, and Preece (2017), Karpowitz and Mendelberg (2018), and others, give reason for caution. 
So too does the possibility that the program might increase the political ambition of male participants while decreasing it among female participants. The program might communicate to young women that politics involves challenges and electoral competition (Kanthak and Woon, 2015; Foos and Gilardi, 2020) and that politics requires the sort of self-promotion that they in particular have been socialized to avoid (Rudman, 1998; Moss-Racusin and Rudman, 2010)

To measure the impact of the program on political ambition, following a pre-registered design, in 2019 we surveyed subjects before and after they participated in L'Taken. We measured participants' political ambition, political efficacy and sense of Jewish identity. Prior to participation, we gathered baseline survey data, including participant gender. Participants received invitations to take each survey via text message. By leveraging the as-if randomness of the specific time period during which an individual participated matched to multiple pre- and postparticipation surveys, we are able to conduct a difference-in-differences analysis to estimate the effect of participating in the program.

We find that participation in L'Taken boosted female political ambition, especially on their willingness to one day run for political office, to the point at which it became indistinguishable from male political ambition observed prior to participation. In other words, women who completed the program were roughly as politically ambitious as men reported being before they participated in the program. To be clear, male participants remained more ambitious than female participants after the program was complete. Yet we had no reason to expect a co-gender program would increase ambition only for women. On its own, while the program does markedly increase female political ambition, it does not close the gender gap.

But to the best of our knowledge, we offer the first quasi-experimental evidence demonstrating a possible means of increasing the political ambition of high school-aged American women. ${ }^{1}$ The program we study takes participants before the gender gap in ambition is ex-

\footnotetext{
${ }^{1}$ Mo, Conn, and Anderson-Nilsson (2019) find that participating in Teach For America after college causes
} 
pected to widen substantially (Fox and Lawless, 2014). As researchers before us have found (Ashby and Schoon, 2010; Schoon, 2001; Schoon and Parsons, 2002; Trice and McClellan, 1993), career ambitions expressed in adolescence can reverberate into adulthood. Our results may have implications for increasing female political ambition over the long-term. We also offer some suggestive evidence, based on participants' subsequent career paths, that the program's effects on ambition may endure well after participation.

\section{L'Taken, Gender and Political Ambition}

Coming from the Hebrew phrase "l'taken olam," meaning "to repair the world," L'Taken is a weekend program for U.S. high school students put on by the Religious Action Center of Reform Judaism (known as the RAC), the political advocacy arm of the Union for Reform Judaism. We conducted this study in 2019, when there were six distinct L'Taken sessions, spread over six different weekends from January to March. Each L'Taken session takes place over three days, attracting hundreds of high school students from across the United States to Washington, D.C.

Several features of the program suggest it may be capable of increasing political ambition. On the first two days of each L'Taken session, participants receive extensive training in political persuasion and advocacy. They manage a mock political action committee, communicate with mock legislators, stage simulated protests and organize mock social media campaigns. On the third day, participants meet with their Members of Congress and/or Congressional staffers, during which time they express their concerns about policy issues of interest to them. Participants can choose which issue to lobby on from a list provided to them by the RAC. In 2019, the issues were gun violence, climate change, LGBTQ rights, reproductive rights, immigration reform, disability rights, criminal justice, Israel, campaign finance reform, church and state iswomen to be more politically ambitious. Here, we study high school students. 
sues, the minimum wage, voting rights and refugee resettlement. (The RAC does not record which students lobbied for which issues.)

The program may heighten participants' sense of political efficacy - their belief that they are able to make a political difference. A sense of political efficacy has repeatedly been described as a prerequisite for political ambition and activity (Bobo and Gilliam, 1990; Fox and Lawless, 2010). The L'Taken program schedules meetings between participants and their Members of Congress or staff, and then lets them advocate for an issue of importance to them. Participants are not conscripted on behalf of one particular partisan or interest group cause. Instead, participants are given the training and opportunity to advocate for an issue of their own choosing, heightening the amount of political efficacy. For many participants, a meeting with their representatives and representatives' staff members might constitute the first time they have had "voice" — that crucial political variable (e.g., Schlozman, Verba, and Brady, 2012)—particularly in front of an audience of national representatives.

The training and lobby days proceed as follows. In the main training portion of the program, dubbed "Kesef Koach Politica," Hebrew which translates as "money, power and politics" in English, participants are enlisted in a political simulation about an issue of the day. The subject of the simulation changes every year; in 2019, the subject was gun control. Over each 2019 L’Taken weekend, during Kesef Koach Politica, participants were assigned into one of two (fictitious) groups, either "Jews Against Guns," a Jewish pro-gun control group, or the "Jewish Rifle Association," a Jewish analogue to the NRA. They were then broken into smaller teams in which they focused on their respective group's messaging and campaign contribution strategy. Specifically, students chose to join teams focused on trying to directly persuade (mock) legislators, draft social media content and television advertisements, organize rallies, and manage the campaign contributions of their side's political action committee. While framed as a competition over a gun control bill, at the end of the competition it was revealed that the "Jewish Rifle 
Association" always had more funding, which ensured the failure of the bill.

For "lobby day," which takes place after the completion of the training, program participants travel to Capitol Hill and split up based on the issues they have chosen and their state and Congressional districts. In each congressional office, program participants deliver 3-5 minute issueadvocacy speeches which they have pre-written with the RAC's assistance. Every participant delivers at least part of a speech; the speeches are frequently delivered by multiple participants. Participants meet with their House member or that member's staff, as well as their state's two Senators or the Senators' staffs. Most meetings last between fifteen and thirty minutes. By the end of the L'Taken program, every program participant has met with three Congressional offices and delivered at least part of one speech.

Both the training and lobby day may impart precisely the sort of civic and political skills necessary for political participation (Brady, Verba, and Schlozman, 1995). Program participants effectively learn how to lobby and enact political change, first in a simulation and then on Capitol Hill. This skill cultivation may increase female participants' self-confidence about politics, which stands out as an especially powerful predictor of political ambition for high school women (Fox and Lawless, 2014). The training and meetings might also upend female participants' expectations about their own social roles, overcoming gendered stereotypes that politics is a masculine domain (Schneider and Bos, 2019). When female L'Taken participants receive political training and meet with political staffers, they can learn that they are suitable for roles related to politics. Moreover, if female participants meet with female representatives or staffers during lobby day, those representatives might serve as role models who fuel their own ambition. Previous work gives strong indication that there may be just such a role model effect (e.g., Campbell and Wolbrecht, 2006; Beaman et al., 2012; Bonneau and Kanthak, 2018; Ladam, Harden, and Windett, 2018; Greenlee, Holman, and VanSickle-Ward, 2014). ${ }^{2}$

\footnotetext{
${ }^{2}$ We are unable to compare the effectiveness of L'Taken on individuals who were exposed to same-gender role models to those who were not. Among the female participants who took a baseline survey, only $1.1 \%$ met with at
} 
The program's religious orientation also bodes well for its potential impact on political ambition. Prior studies have shown that adolescents involved with religious organizations are more politically active than their less religious counterparts (e.g., Andolina et al., 2003). Furthermore, the program promoted communal goals (Schneider et al., 2016) by explicitly linking the Jewish values of the participants to political involvement, religious and values-based rhetoric that might prove particularly effective (Blankenship, Wegener, and Murray, 2012; Margolis, 2018). (As we found, however, the pre-program levels of political ambition among participants were similar to those observed on national samples of high schoolers planning to attend college. We describe that finding below.)

The program's focus on high schoolers is another source of promise. Adolescence stands out as an especially crucial time in the political life cycle (Jennings and Niemi, 1974, 1981). Partisan attachments, transmitted via the parents, are often solidified during this time (Niemi and Jennings, 1991). Participation in voluntary associations during this period, such as student council, religious organizations and drama clubs, powerfully predict adult political participation (McFarland and Thomas, 2006). Broadly speaking, it is during these "impressionable years" (Krosnick and Alwin, 1989) that one can acquire the civic skills necessary for subsequent participation in political life (Brady, Verba, and Schlozman, 1995).

Yet L'Taken is not designed to increase political ambition and efficacy. Students are never separated along gender lines, and gender and ambition are never discussed. In expectation, certain elements of the program may be more conducive to ambition and efficacy increases than others. The lobby day would seem to represent a possible means of increasing both outcomes; for many participants, those interactions may represent the first instance of engagement they have had with their national representatives. On the other hand, the "Kesef Koach Politica" least one female Member of Congress and $89.2 \%$ met with at least one female staffer. Among the male participants who took a baseline survey, $6.1 \%$ met with at least one male Member of Congress and $88.2 \%$ met with at least one male staffer. This limited exposure to Members of Congress and the lack of variation in exposure to same-gender staffers precludes the desired comparison. 
training program's overriding focus on the role of money in politics may cultivate cynicism among participants, as may have also occurred inadvertently during the intervention of Foos and Gilardi (2020).

More generally, despite the many reasons which might lead one to suspect it capable of increasing political ambition, L'Taken is hardly guaranteed to increase the political ambition of female participants. One possibility is that L'Taken might increase political ambition among male participants while decreasing it among female participants. Indeed, participation might reduce the political ambition of female participants. First, if in order to succeed in politics, women need to be substantially more qualified than men (Anzia and Berry, 2011; Besley et al., 2017; O’Brien and Rickne, 2016; Fulton, 2012; Milyo and Schosberg, 2000), this exposure to "superstar" female Members of Congress and staff may present role models who are unrelatable and whose successes seem unattainable to female participants. This exposure could unintentionally demoralize female participants and backfire by reducing their political ambition (Asgari, Dasgupta, and Stout, 2012; Lockwood and Kunda, 1997). Second, when female politicians speak candidly to female college students interested in politics about their experiences in politics, including the challenges they faced, they might fail to increase political ambition (Foos and Gilardi, 2020). Third, exposure to lobbying may teach female participants that politics demands competition, reinforcing female participants' aversion to electoral competition (Kanthak and Woon, 2015). Finally, participation in L'Taken may communicate to female participants that political ambition requires self-promotion, which they may have been otherwise socialized to avoid (Rudman, 1998; Moss-Racusin and Rudman, 2010). For these reasons, it is not obvious whether programs such as L'Taken, which provide civic training and exposure to politicians and high-powered staff, will necessary increase political ambition among female participants, even if it does among male participants.

Yet if L'Taken were to prove capable of increasing female political ambition, it would do so 
during a particularly opportune time in the life cycle of political ambition. In school curricula, children are often presented with gender-stereotypical descriptions of political leaders where politics is portrayed as a stereotypical masculine field (Lay et al., 2021). By college, roughly twice as many men than women report thinking about running for office "many times" (Fox and Lawless, 2014; Lawless and Fox, 2014). While educational attainment, family background (Ashby and Schoon, 2010) and sociohistorical factors (Schoon and Parsons, 2002) have large roles to play, ambitions expressed in adolescence can wield great influence over adult career choice (Ashby and Schoon, 2010; Schoon, 2001; Schoon and Parsons, 2002), for both men and women (Trice and McClellan, 1993). When it comes to the political ambition of its participants, the stakes of L'Taken are considerable (Shames, 2017a).

\section{Research Design}

To investigate the program's effects on political ambition and efficacy, in 2019 we surveyed L'Taken participants before and after they participated in the program. The first L'Taken program occurred on January 11 while the last took place on March 15, with four in between. Participants only attended a single weekend; the weekend during which an individual participated was determined based on the scheduling availability of their Members of Congress. Because more ambitious individuals could not select into participating earlier, the weekend during which an individual participated was therefore expected to be as-if random. We administered our first survey on January 3rd and administered our last on April 1, for a total of six surveys. The number of surveys that one was asked to complete before and after participating in L'Taken varied based on the L'Taken program date one signed up for.

Overall, 916 individuals completed an average of 2.2 surveys each. ${ }^{3}$ To understand how

\footnotetext{
${ }^{3}$ Because of an error, we deviated from our Pre-Analysis Plan and did not administer a post-treatment survey on March 20th.
} 
this proceeded in practice, see Table 1, which displays L'Taken cohort date and corresponding survey dates, as well as information about which surveys took place before or after the program date for that cohort. For example, the January 11th cohort received one pre-treatment survey, on January 3rd, and then received six post-treatment surveys, beginning January 18th and ending April 1. The February 25th cohort, meanwhile, received three surveys prior to their program date, and then three surveys afterwards. On average, six days elapsed between participating in the L'Taken program and the initial post-program survey. Despite the attrition between the pre- and post-surveys, we find that individuals who take both the pre- and post-surveys have similar levels of baseline political ambition and efficacy as those who attrit and only take the pre-survey.

Table 1: Cohort and Survey Dates (sample sizes in parentheses)

\begin{tabular}{|c|c|c|c|c|c|c|}
\hline & Jan 11 Cohort & Jan 25 Cohort & Feb 8 Cohort & Feb 25 Cohort & March 1 Cohort & March 15 Cohort \\
\hline Pre-Survey 1 & $\begin{array}{l}\text { 3-Jan } \\
\text { (130) }\end{array}$ & $\begin{array}{l}\text { 3-Jan } \\
(130)\end{array}$ & $\begin{array}{c}\text { 3-Jan } \\
\text { (99) }\end{array}$ & $\begin{array}{c}\text { 18-Jan } \\
(70)\end{array}$ & $\begin{array}{c}\text { 31-Jan } \\
(66)\end{array}$ & $\begin{array}{c}\text { 14-Feb } \\
\text { (41) }\end{array}$ \\
\hline Pre-Survey 2 & N/A & $\begin{array}{c}\text { 18-Jan } \\
(81)\end{array}$ & $\begin{array}{c}\text { 18-Jan } \\
(51)\end{array}$ & $\begin{array}{c}\text { 31-Jan } \\
(35)\end{array}$ & $\begin{array}{c}\text { 14-Feb } \\
\text { (39) }\end{array}$ & $\begin{array}{c}\text { 28-Feb } \\
\text { (33) }\end{array}$ \\
\hline Pre-Survey 3 & N/A & N/A & $\begin{array}{c}\text { 31-Jan } \\
(60)\end{array}$ & $\begin{array}{c}\text { 14-Feb } \\
(37)\end{array}$ & $\begin{array}{c}\text { 28-Feb } \\
(57)\end{array}$ & $\begin{array}{c}\text { 6-Mar } \\
(21)\end{array}$ \\
\hline Post-Survey 1 & $\begin{array}{c}\text { 18-Jan } \\
(82)\end{array}$ & $\begin{array}{c}\text { 31-Jan } \\
(119)\end{array}$ & $\begin{array}{c}\text { 14-Feb } \\
(94)\end{array}$ & $\begin{array}{c}28-\mathrm{Feb} \\
(91)\end{array}$ & $\begin{array}{c}\text { 6-Mar } \\
(58)\end{array}$ & $\begin{array}{c}\text { 1-Apr } \\
(28)\end{array}$ \\
\hline Post-Survey 2 & $\begin{array}{c}\text { 31-Jan } \\
(55)\end{array}$ & $\begin{array}{c}\text { 14-Feb } \\
(77)\end{array}$ & $\begin{array}{c}28-\mathrm{Feb} \\
(61)\end{array}$ & $\begin{array}{c}\text { 6-Mar } \\
(60)\end{array}$ & $\begin{array}{c}\text { 1-Apr } \\
\text { (37) }\end{array}$ & N/A \\
\hline Post-Survey 3 & $\begin{array}{c}\text { 14-Feb } \\
\text { (26) }\end{array}$ & $\begin{array}{c}28-\mathrm{Feb} \\
(45)\end{array}$ & $\begin{array}{c}\text { 6-Mar } \\
(42)\end{array}$ & $\begin{array}{c}\text { 1-Apr } \\
(42)\end{array}$ & N/A & N/A \\
\hline Post-Survey 4 & $\begin{array}{c}28-\mathrm{Feb} \\
(23)\end{array}$ & $\begin{array}{c}\text { 6-Mar } \\
\text { (39) }\end{array}$ & $\begin{array}{c}\text { 1-Apr } \\
(40)\end{array}$ & N/A & N/A & N/A \\
\hline Post-Survey 5 & $\begin{array}{c}\text { 6-Mar } \\
\text { (16) }\end{array}$ & $\begin{array}{c}\text { 1-Apr } \\
\text { (38) }\end{array}$ & N/A & N/A & N/A & N/A \\
\hline Post-Survey 6 & $\begin{array}{l}\text { 1-Apr } \\
(6)\end{array}$ & N/A & N/A & N/A & N/A & N/A \\
\hline
\end{tabular}

The surveys were distributed to program participants via text message. The text messages were identified as originating from the RAC and directed recipients to follow a link to complete a survey. Though they were not offered compensation, the RAC did organize a raffle of \$50 Amazon gift cards for each survey, with eligibility determined by survey completion. The 
complete text of communications sent to recipients appears in the appendix. To increase survey uptake, during each L'Taken weekend the RAC staff urged all participants to complete the surveys they would soon receive. Although participants were aware that researchers were studying the L'Taken program, RAC staff members did not disclose the purpose of the study to program participants.

To measure political ambition, we asked subjects three questions. We asked them, "How likely is it that, someday, when you're older, you might want to..." and then presented them with 1-7 likelihood scales. Specifically, we asked them about how likely it would be that they would "run for political office," "work on a political campaign," and "work for the government." Higher values signaled greater likelihood. In order to reduce measurement error, we report an index of the average value across these three items (Ansolabehere, Rodden, and Snyder, 2008). We also report the effect specifically on "run for political office," as this has been a primary outcome of interest within the political ambition literature (e.g., Fox and Lawless, 2004, 2010, 2014). All outcome measures were pre-specified in our pre-analysis plan. For interpretability, we transform all measures to have mean 0 and standard deviation 1 , with higher values indicating greater ambition.

To measure political efficacy, we presented subjects with two statements and asked them to state their levels of agreement on 1-7 scales, with higher values again signaling greater agreement. The statements were "Ordinary citizens can do a lot to influence the government in Washington if they are willing to make the effort" and "It's important to me to let my political representatives know how I feel about the issues." Again, we combined these two items into a political efficacy index by averaging the two items and standardizing.

In the baseline pre-treatment surveys, we find that on two of the three ambition items, men have higher political ambition while women have higher political efficacy (see Table 2). ${ }^{4}$ In

\footnotetext{
${ }^{4}$ It is interesting to note that more women participated in L'Taken than men. This is consistent with prior
} 
particular, we find that men are much more likely to consider running for office than women while women are more likely to consider working for a political campaign than men. However, our finding that women have greater feelings of political efficacy than men is somewhat surprising given past research (e.g., Preece, 2016; Verba, Burns, and Schlozman, 1997). As we discuss in more detail below, this difference may be related to how conceptions of political ambition differ by sex (Schneider et al., 2016), and is consistent with broader patterns regarding gender and political efficacy, especially shortly after the "Year of the Women," when this study was conducted (Lawless and Fox, 2018). ${ }^{5}$

Table 2: Summary of Baseline Ambition and Efficacy Views

\begin{tabular}{|c|c|c|}
\hline & Female Average & Male Average \\
\hline \multicolumn{3}{|l|}{ Ambition Items } \\
\hline Run for political office - \% Likely & $25 \%$ & $35 \%$ \\
\hline Work on a political campaign - \% Likely & $49 \%$ & $44 \%$ \\
\hline Work for the government - \% Likely & $40 \%$ & $42 \%$ \\
\hline \multicolumn{3}{|l|}{ Efficacy Items } \\
\hline Ordinary citizens can do a lot to influence the government in Washington if they are willing to make the effort - \% Agree & $91 \%$ & $76 \%$ \\
\hline It's important to me to let my political representatives know how I feel about the issues - \% Agree & $92 \%$ & $85 \%$ \\
\hline $\mathrm{N}$ & 435 & 262 \\
\hline
\end{tabular}

Among the participants who completed more than one pre-treatment survey, we find that measures of political ambition and efficacy are highly stable. Across the first two pre-treatment survey waves, the ambition index has a correlation coefficient of 0.86 and the efficacy index has a correlation coefficient of 0.59 . The high temporal stability of these two measures is encouraging for the validity of the difference-in-differences design (Wing, Simon, and BelloGomez, 2018, p. 460).

Finally, we asked subjects if they identified as male, female, or other, and provided a text box for those who chose the third option. We only asked this question on surveys administered before L’Taken participation. ${ }^{6}$

evidence showing that young Jewish men are far less likely to participate in communal-religious spaces than young Jewish women (e.g., Whitehead-Bust, 2010).

${ }^{5}$ Costa and Wallace (2021) similarly find that women in their survey tend to have higher levels of political efficacy than men and lower levels of ambition. Future work should explore this pattern.

${ }^{6} 11$ individuals identified as other than male or female. Two hundred and eight individuals only took the post- 
To estimate the effect of L'Taken using a difference-in-differences design, our analyses estimated the following equation:

$$
y_{i, t}=\gamma_{t}+\tau \omega_{i, t}+\alpha_{i}+\mu_{i, t} ; t=0, \ldots, 7 ; i=1, \ldots, N,
$$

where $\gamma_{t}$ is an indicator for the time period, $\omega_{i, t}$ is an indicator for whether individual $i$ attended L'Taken before $t$ (such that as soon as an individual participates between $t-1$ and $t$, this indicator is set to 1 and then is then always coded as 1 for all time periods thereafter), $\alpha_{i}$ is an individual-level fixed effect, $\mu_{i, t}$ are the idiosyncratic errors clustered at the individual level $i$, and $\tau$ is the treatment effect of participating in L'Taken that we are estimating. In some specifications, we subset only to where individual $i$ self-identified as either male or female in an initial, pre-L'Taken survey. ${ }^{7}$

\section{Results}

L'Taken's participants may have higher baseline levels of political ambition than some nationally representative samples of young people. In our first baseline survey, prior to participating in L'Taken, $35 \%$ of men and $25 \%$ of women reported that they would be at all likely to run for office, with $6 \%$ of men and $4 \%$ of women being extremely likely. In Lawless and Fox (2015, Table 2.1), $13 \%$ of young male respondents and $8 \%$ of young female respondents report that they would consider running for office in the future. However, Fox and Lawless (2014, Appendix C) find that around 30-40\% of both male and female high school students who plan to attend college report having considered running for office. While we do not have data on

treatment surveys; we have no such data on these participants. For the main results, we limit our analyses only to those participants who took at least one pre-treatment survey as pre-treatment survey measures are likely to reduce bias and increase precision. In the supplementary materials, we report results with all participants. Future research should take a more inclusive approach to gender identity.

${ }^{7}$ In $R$, this equation would be estimated as follows: felm(data[,dv] $\sim \operatorname{post}+$ as.factor(date) $\mid$ id $|0|$ id, data $=$ data) 
whether L'Taken participants plan to attend college, our data suggest that participants' political ambition levels resemble those observed in samples of young people planning to attend college.

Figure 1 displays results for our three pre-registered and primary outcomes: the ambition index, the efficacy index, and whether an individual expresses an interest in running for office, as measured on the standardized 7-point scale. ${ }^{8}$ In addition, for ease of interpretation, Figure 1 presents results on a version of the running for office measure where participants who reported being "Extremely likely," "Moderately likely," or "Slightly likely" to run for office are coded as 1 and all other responses are coded as 0 . We present results for each outcome by gender. We conducted these surveys an average of six days after participating in L'Taken. Similarly, Figure 2 shows the treatment effects over time. In this figure, we subset our data to three posttreatment time periods: 1-7 days post-treatment (mean of 5.5 days), 8-26 days post-treatment (mean of 18.6 days), and 27-80 days post-treatment (mean of 44.2 days). These time periods were selected to ensure comparable sample sizes across time, but this analysis was not prespecified.

Our results are clear: L'Taken increased political ambition and efficacy across genders, including positive effects on both men's and women's interest in eventually running for office. On the ambition index, among female participants the program caused a .260 standard deviation increase $(S E=0.065 ; p<0.001) .{ }^{9}$ The overall effect on the ambition index was a .220 standard deviation increase ( $S E=0.047 ; p<0.001)$, an effect that appears to persist at least several weeks post-treatment. Though the effect was larger for women than men, this difference was not statistically significant $(p=0.712)$.

Focusing on the run-for-office outcome, among female participants we detect an effect of .252 standard deviations $(S E=0.065 ; p<0.001$ ). The overall effect on this outcome was .215

\footnotetext{
${ }^{8}$ Note that these estimates reflect our standardized scale to have mean 0 and standard deviation 1 , with higher values corresponding with higher levels of political ambition and efficacy.

${ }^{9} \mathrm{All}$ p-values are two-tailed given prior evidence that events intending to increase female political ambition may actually have the reverse effect (Foos and Gilardi, 2020).
} 
standard deviations $(S E=0.050 ; p<0.001)$. While effects were larger for female participants than male participants, the difference is again not significant $(p=0.690)$. However, as shown in Figure 2, the effects may be more likely to persist among female participants than male participants, although this difference is not statistically significant. Among all subjects, we find that the program increased the number of participants who reported being "Extremely likely," "Moderately likely," or "Slightly likely" by 9.7 percentage points $(S E=0.028 ; p=0.001)$.

We had no reason to suspect that the program would affect members of one gender more than another, and indeed that was not the case, although the effect was nearly double for female participants. Additional robustness tests are reported in the supplementary materials.

To put the effects on ambition among female participants in context, consider the following. Prior to program participation, 35\% of male participants stated they were "Extremely likely," "Moderately likely," or "Slightly likely" to run for office compared to $25 \%$ of female participants. However, after participating, $32 \%$ of female participants stated they were likely to run for office. In other words, after participating in the program, women were almost as interested in running for office as men were before participating. L'Taken did not close the gender gap in ambition, but it did increase political ambition among female participants. (We consider this point further in the discussion section.)

On the efficacy index, the increase for women was .214 standard deviations $(S E=0.095 ; p=$ 0.025); the overall effect on the efficacy index was .265 deviations $(S E=0.077 ; p=0.001)$. And again, the difference between genders was not significant $(p=0.800)$. Interestingly, prior to treatment, female respondents reported higher levels of efficacy than male respondents. Higher levels of efficacy reported by females may be attributable to the way in which attitudes toward political ambition differ by sex. Females who view political ambition as tied up in communal goals, as described by Schneider et al. (2016), may believe they can make contributions to their communities in ways outside of elected office. In contrast, men may view elected of- 
$\neg$ Baseline $\multimap$ Post
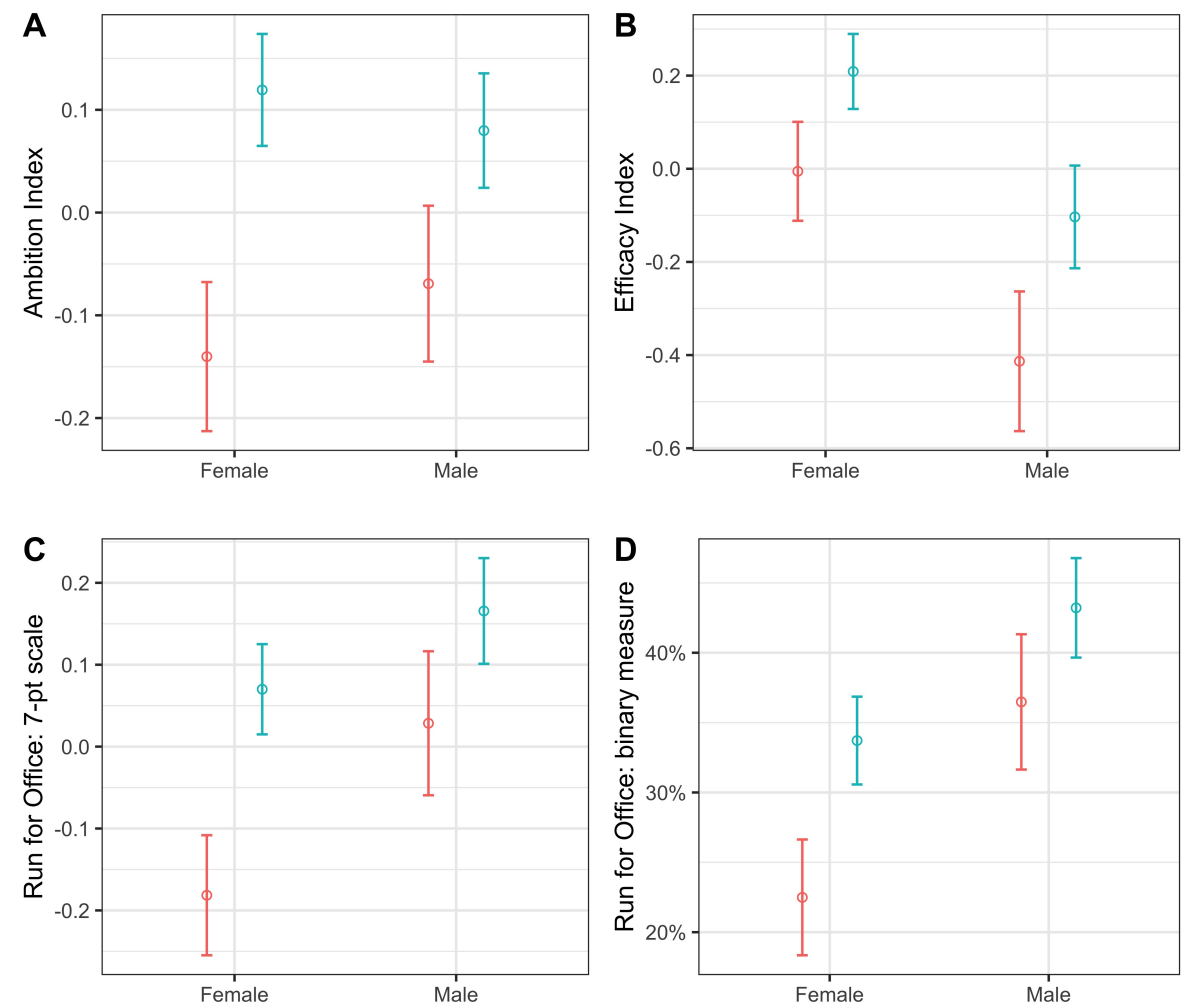

Note: for all outcomes, no differences in the treatment effect of L'Taken between male and female respondents were statistically significant.

Figure 1: Effects of L'Taken. We find that L'Taken increased political ambition, efficacy, and participants' likelihood of running for office. L'Taken was similarly effective among both men and women. Numerical results are reported in Tables OA3-6.

fice as their best bet to advance their power and interests, in accordance with their distinctive conception of political ambition.

Sex-based differences in efficacy among our participants also reflect broader patterns observed during the "year of the women" that followed the 2018 midterm elections, when this study was being conducted. As Lawless and Fox (2018) show, although more women were politically engaged during this time, the gender gap in ambition specifically did not narrow. Heightened efficacy may heighten participation in general (Bobo and Gilliam, 1990), without necessarily increasing ambition for office. Our pre-treatment data makes this point clear: 


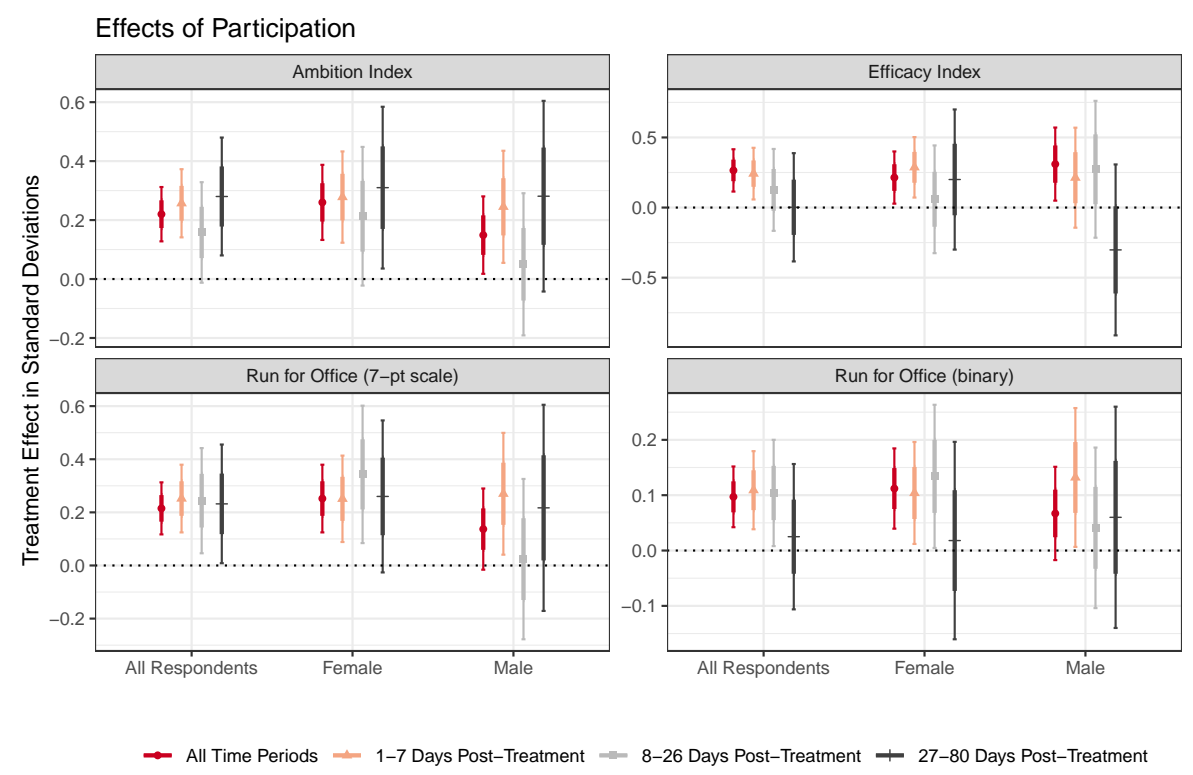

Figure 2: Effects of L'Taken across time periods. Numerical results are reported in Tables OA15-18.

Higher levels of efficacy do not necessarily translate to higher levels of ambition for elected office. To be clear, however, this explanation is only speculative, and could be a feature unique to this sample of Reform Jews.

In addition to examining political efficacy and ambition, we also investigated whether participation in L'Taken increased feelings of Jewish identity. In the surveys we asked participants three questions on to what extent they feel: "a connection to the American Jewish community," "a connection to the Jewish community where you live," and "a connection to Jewish customs and traditions." We also asked respondents whether they agree or disagree that their "political beliefs are connected to [their] Jewish identity." As this was not a primary research interest, we did not include a discussion of these items in our pre-analysis plan. However, we analyze them using the same approach that we pre-specified for our efficacy and ambition outcomes.

On the three outcomes about Jewish connection, we find small and statistically insignificant findings. The effect on "American Jewish community" is 0.124 standard deviations $(S E=$ 
$0.079 ; p=0.115)$; on "where you live" it is 0.021 standard deviations $(S E=0.075 ; p=$ $0.782)$; and on "Jewish customs and traditions" it is 0.036 standard deviations $(S E=0.063 ; p=$ 0.563). We see no statistically significant differences between male and female participants. These null findings on Jewish identity are consistent with the results on political efficacy and ambition not being driven by demand effects; the difference-in-differences design used here is capable of producing null results. It is worth noting, however, that these three items also had high baseline values in the surveys conducted before L'Taken participation. On each item, the average baseline response was between "Somewhat" and "Very much," the highest response level. Participants in L'Taken already had high levels of Jewish identity (see Table OA1 in the Supplementary Materials for further details).

But on the outcome linking political beliefs to participants' Jewish identity, we do find meaningful effects. Baseline values on this question were substantially lower. We find that participation in L'Taken, a program that explicitly links political engagement to Jewish identity, increases respondents beliefs that their politics and Judaism are linked by 0.175 standard deviations $(S E=0.071 ; p=0.015)$, with similar effects for both male and female respondents. While our design does not allow us to isolate the effect of the Jewish component of L'Taken from the trainings and lobbying, this result suggests that religious values may be an important mechanism through which a community can instill civic values and encourage political ambition.

\section{Discussion and Conclusion}

Identifying the determinants of who runs for political office—and who does not—represents a major research challenge, with pressing political and policy stakes (Hall, 2019). In the United States, women have been under-represented as both candidates and office-holders. Numerous explanations have been offered, including the absence of role models (Campbell and Wolbrecht, 
2006; Kalla, Rosenbluth, and Teele, 2018), the "gendered psyche" (Preece, 2016), gender differences in attitudes toward participating in competitive elections (Kanthak and Woon, 2015; Preece and Stoddard, 2015), challenges in fundraising (Jenkins, 2007; Thomsen and Swers, 2017), amount and tone of media coverage (Kahn, 1992; Kittilson and Fridkin, 2008; but see Hayes and Lawless, 2016), among other explanations. These accounts are not mutually exclusive, nor do they foreclose a different explanation: comparatively low levels of female political ambition. At least since Schlesinger (1966), scholars have emphasized that running for office requires a larger amount of political ambition than observed in the broader population. As Fox and Lawless $(2004,2010,2014)$ have shown more recently, the gender-based gap in ambition plays a role in the inordinately small number of female candidates, despite the absence of overt sex-based discrimination they face at the ballot box (Lawless and Pearson, 2008; Seltzer, Newman, and Leighton, 1997; Teele, Kalla, and Rosenbluth, 2018).

Following a pre-registered design, we find that the L'Taken program is capable of increasing political ambition and efficacy among its high school participants. While the effects are not restricted to women, it is the case that after participating, women were about as interested in running for office as their male counterparts were before participating. This increase was observed even though the program neither overtly referred to the gender gap nor separated participants along gender lines.

While the L'Taken program does not eliminate the gender gap in ambition, our results make clear that it enhances the political ambition of young women. What does this mean for closing the gender gap in representation? One possibility is that, to close the gender gap in representation, it may not be necessary to close the gap in ambition. The decision to run for office may follow a threshold model; once ambition surpasses a certain threshold, an individual chooses to run. If this is the case, programs such as L'Taken could increase the supply of female candidates, even without closing the gender gap in ambition. Conditional on running for office, 
women tend to be quite successful at winning elections (e.g., Lawless and Pearson, 2008); programs like L'Taken could succeed in closing the gender gap in representation even while increasing the political ambition of both young women and young men. However, whether such a threshold model obtains is beyond the scope of this paper.

Nevertheless, we do have some suggestive evidence that programs such as L'Taken can succeed in encouraging more women to seek office. The effects we observe do not dissipate immediately: As shown in Figure 2, many of the effects appear to persist for at least several weeks. But the more meaningful time horizon is on the order of years, not weeks. Prior research gives reason to believe that career decisions made during adolescence may be especially consequential over the long-term (Ashby and Schoon, 2010; Schoon, 2001; Schoon and Parsons, 2002; Trice and McClellan, 1993). Although we cannot say now what the effects of the L'Taken sessions we studied will be in several years from now, we do have some evidence regarding post-L'Taken career trajectories that may be instructive.

Working with the RAC, we analyzed the public post-L'Taken career trajectories of participants from 2014-2018. A research assistant manually searched and matched the names of L'Taken participants to LinkedIn, Facebook, and other online networks or news sources. Of 213 female participants, we found evidence that $15 \%$ worked on a campaign after L'Taken, while $8.4 \%$ worked for government at any level. Among 235 males, $6 \%$ subsequently worked on a campaign, while $3 \%$ later worked in government. While hardly definitive, this is further evidence in favor of the conclusion that L'Taken affects participants' political behavior, with pronounced effects on females.

Given the details of the program described above, its capacity for long-term effects should not be altogether surprising. Compared to treatments often studied in survey experiments, the treatment we study is longer and more demanding of subjects, and thus perhaps more capable of affecting meaningful political outcomes (Gaines, Kuklinski, and Quirk, 2007). As the above 
evidence on career trajectories suggest, the effects of L'Taken may last long enough to matter in real-world scenarios-in our case, when a person is considering whether to actually pursue a career in politics. Indeed, as described above, we already have some evidence of effect duration.

That having been said, we cannot specify what worked about the L'Taken program. The program featured multiple components, each of which, in theory, could have increased women's political ambition. It may have been the lobbying experience of meeting with a Member of Congress or their staff and being heard on an issue import to them; it may have been the training participants received beforehand, teaching them essential skills for politics. By the same token, certain aspects of the program may have diminished the observed effects, such as cynicism about the role of money in politics. Future research should disentangle that various aspects of this program, and any others found to have similar effects, to understand what, specifically, is responsible for the increase in female political ambition.

Two outstanding concerns, related to internal validity, remain. First, as this was not a randomized experiment but instead relied on a difference-in-differences design, we may be worried about violations of parallel trends. And because everyone eventually attended L'Taken in this design, we are unable to study any longer-term impacts of participation. Second, given that the surveys were fielded by the RAC, we may worry that participants overstated their post-treatment political ambition, exemplifying demand effects. Broadly, recent empirical evidence shows that fears of demands effects can be overstated (Mummolo and Peterson, 2019). In our study specifically, the null findings on the Jewish identity items also helps assuage such concerns. While participants had initially high levels of Jewish identity, the program does not appear to have pushed them higher.

In addition, the extent to which our findings generalize to non-religious political programs for adolescents is unclear. We do not know whether the program's effectiveness at increasing ambition is inextricable from its religious background. Adolescents involved in religious groups 
are already more prone to political activity than their counterparts (e.g., Andolina et al., 2003), which may have made them especially susceptible to this program.

A related concern for generalizability is that L'Taken participants are Reform Jews. Jews in America, and Reform Jews in particular, are substantially more likely to identify as white and as Democrats than the general population (Pew Research Center, 2013; Hersh and Malina, 2017). Future work should consider the efficacy of programs like L'Taken among more conservative and Republican young women and through an intersectional lens (Shames, 2017b). While further work on non-religious programs is warranted, the similarity in baseline levels of political ambition among those planning to attend college is promising for the generalizability of these results, at least to college-bound young people.

For those interested in increasing female political ambition, the fact that we attribute an increase to a religious program may offer a way forward. As Schneider et al. (2016) show, the gender gap in political ambition can be eliminated when political careers are framed as serving communal goals, as opposed to advancing the power of the individual politician. By tying politics to religion, the L'Taken program may have been framing politics as communal, in precisely the manner that Schneider et al. (2016) posit can reduce the gender gap. While we do not have data on whether participants' attitudes toward political ambition differed by gender in the ways described by those authors, L'Taken's success at increasing female political ambition may be owed to its recasting of politics as a communal enterprise, intertwined with participants' religion. Other religious and communal groups could offer similar programs for high schoolers that, while not explicitly premised on increasing female political ambition, could ultimately do so nonetheless.

Such follow-up programs, however, would come at a substantial cost. L'Taken is not a lighttouch intervention. Yet while this intervention was costly, it clearly demonstrates the ability to increase female political ambition. Researchers, political organizations and activists interested 
in emulating this approach could potentially use video conferencing to lower costs or to reach more people.

Future research should also unpack the independent effects of exposure to political officials, lobbying officials, and gaining political skills on increasing political ambition. Female-only programs modeled on L'Taken, as well as co-ed programs sponsored by communal and religious efforts, should be analyzed. Such research would clarify whether political ambition can be increased not only among religious, politically-motivated high school Reform Jews, but among the broader U.S. adolescent population.

\section{References}

Andolina, Molly W, Krista Jenkins, Cliff Zukin, and Scott Keeter. 2003. "Habits from home, lessons from school: Influences on youth civic engagement." PS: Political Science \& Politics 36 (2): 275-280.

Ansolabehere, Stephen, Jonathan Rodden, and James M Snyder. 2008. "The strength of issues: Using multiple measures to gauge preference stability, ideological constraint, and issue voting." American Political Science Review 102 (2): 215-232.

Anzia, Sarah F, and Christopher R Berry. 2011. "The Jackie (and Jill) Robinson effect: why do congresswomen outperform congressmen?" American Journal of Political Science 55 (3): $478-493$.

Asgari, Shaki, Nilanjana Dasgupta, and Jane G Stout. 2012. "When do counterstereotypic ingroup members inspire versus deflate? The effect of successful professional women on young womens leadership self-concept." Personality and Social Psychology Bulletin 38 (3): $370-383$. 
Ashby, Julie S., and Ingrid Schoon. 2010. "Career success: The role of teenage career aspirations, ambition value and gender in predicting adult social status and earnings." Journal of Vocational Behavior 77 (3): 350 - 360.

Beaman, Lori, Esther Duflo, Rohini Pande, and Petia Topalova. 2012. "Female leadership raises aspirations and educational attainment for girls: A policy experiment in India." Science 335 (6068): 582-586.

Bernhard, Rachel, Shauna Shames, and Dawn Langan Teele. 2021. "To Emerge? Breadwinning, Motherhood, and Womens Decisions to Run for Office." American Political Science Review 115 (2): 379-394.

Besley, Timothy, Olle Folke, Torsten Persson, and Johanna Rickne. 2017. "Gender quotas and the crisis of the mediocre man: Theory and evidence from Sweden." American Economic Review 107 (8): 2204-42.

Blankenship, Kevin L, Duane T Wegener, and Renee A Murray. 2012. "Circumventing resistance: Using values to indirectly change attitudes." Journal of Personality and Social Psychology 103 (4): 606.

Bobo, Lawrence, and Franklin D Gilliam. 1990. "Race, sociopolitical participation, and black empowerment." American Political Science Review 84 (2): 377-393.

Bonneau, Chris W, and Kristin Kanthak. 2018. "Stronger together: political ambition and the presentation of women running for office." Politics, Groups, and Identities.

Brady, Henry E, Sidney Verba, and Kay Lehman Schlozman. 1995. "Beyond SES: A resource model of political participation." American Political Science Review 89 (2): 271-294. 
Campbell, David E, and Christina Wolbrecht. 2006. "See Jane run: Women politicians as role models for adolescents." The Journal of Politics 68 (2): 233-247.

Carroll, Susan J, and Richard L Fox. 2018. Gender and elections: Shaping the future of American politics. Cambridge University Press.

Costa, Mia, and Isabel Wallace. 2021. "More Women Candidates: The Effects of Increased Women's Presence on Political Ambition, Efficacy, and Vote Choice." American Politics Research.

Epstein, Rachel. 2018. "6 Political Candidate Organizations Helping Women Run for Office.” Marie Claire.

URL: https://www.marieclaire.com/politics/a23678900/women-political-organizations-runfor-officel

Foos, Florian, and Fabrizio Gilardi. 2020. "Does exposure to gender role models increase womens political ambition? A field experiment with politicians." Journal of Experimental Political Science 7 (3): 157-166.

Fox, Richard L, and Jennifer L Lawless. 2004. "Entering the arena? Gender and the decision to run for office.” American Journal of Political Science 48 (2): 264-280.

Fox, Richard L, and Jennifer L Lawless. 2010. "If only they'd ask: Gender, recruitment, and political ambition.” The Journal of Politics 72 (2): 310-326.

Fox, Richard L, and Jennifer L Lawless. 2014. "Uncovering the origins of the gender gap in political ambition.” American Political Science Review 108 (3): 499-519.

Fulton, Sarah A. 2012. "Running backwards and in high heels: The gendered quality gap and incumbent electoral success.” Political Research Quarterly 65 (2): 303-314. 
Gaines, Brian J., James H. Kuklinski, and Paul J. Quirk. 2007. "The Logic of the Survey Experiment Reexamined.” Political Analysis 15 (1): 120.

Greenlee, Jill S, Mirya R Holman, and Rachel VanSickle-Ward. 2014. "Making it personal: Assessing the impact of in-class exercises on closing the gender gap in political ambition." Journal of Political Science Education 10 (1): 48-61.

Hall, Andrew. 2019. Who Wants to Run? How the Devaluing of Political office Drives Polarizaiton. University of Chicago Press.

Hayes, Danny, and Jennifer L Lawless. 2016. Women on the run: Gender, media, and political campaigns in a polarized era. Cambridge University Press.

Hersh, Eitan D, and Gabrielle Malina. 2017. "Partisan Pastor: The Politics of 130,000 American Religious Leaders.” Working Paper.

Jenkins, Shannon. 2007. “A woman's work is never done? fund-raising perception and effort among female state legislative candidates.” Political Research Quarterly 60 (2): 230-239.

Jennings, M Kent, and Richard G Niemi. 1974. Political character of adolescence: The influence of families and schools. Princeton University Press.

Jennings, M Kent, and Richard G Niemi. 1981. Generations and politics: A panel study of young adults and their parents. Princeton University Press.

Kahn, Kim Fridkin. 1992. "Does being male help? An investigation of the effects of candidate gender and campaign coverage on evaluations of US Senate candidates." The Journal of Politics 54 (2): 497-517. 
Kalla, Joshua, Frances Rosenbluth, and Dawn Langan Teele. 2018. "Are you my mentor? A field experiment on gender, ethnicity, and political self-starters." The Journal of Politics 80 (1): $337-341$.

Kanthak, Kristin, and Jonathan Woon. 2015. “Women don't run? Election aversion and candidate entry." American Journal of Political Science 59 (3): 595-612.

Karpowitz, Christopher F., J. Quin Monson, and Jessica Robinson Preece. 2017. "How to Elect More Women: Gender and Candidate Success in a Field Experiment." American Journal of Political Science 61 (4): 927-943.

Karpowitz, Christopher F., and Tali Mendelberg. 2018. "Do Enclaves Remediate Social Inequality?" The Journal of Politics 80 (4): 1134-1149.

Kittilson, Miki Caul, and Kim Fridkin. 2008. "Gender, candidate portrayals and election campaigns: A comparative perspective." Politics \& Gender 4 (3): 371-392.

Krosnick, Jon A, and Duane F Alwin. 1989. "Aging and susceptibility to attitude change." Journal of personality and social psychology 57 (3): 416.

Ladam, Christina, Jeffrey J Harden, and Jason H Windett. 2018. "Prominent Role Models: High-Profile Female Politicians and the Emergence of Women as Candidates for Public Office." American Journal of Political Science 62 (2): 369-381.

Lawless, J, and R Fox. 2014. 'Not a'Year of the Woman' and 2036 Doesn't Look So Good Either." Governance Studies at Brookings.

Lawless, Jennifer L, and Kathryn Pearson. 2008. “The primary reason for women's underrepresentation? Reevaluating the conventional wisdom.” The Journal of Politics 70 (1): 67-82. 
Lawless, Jennifer L, and Richard L Fox. 2015. Running from office: Why young Americans are turned off to politics. Oxford University Press.

Lawless, Jennifer L., and Richard L. Fox. 2018. “A Trump Effect?” The Forum.

Lay, J Celeste, Mirya R Holman, Angela L Bos, Jill S Greenlee, Zoe M Oxley, and Allison Buffett. 2021. “TIME for Kids to Learn Gender Stereotypes: Analysis of Gender and Political Leadership in a Common Social Studies Resource for Children.” Politics \& Gender 17 (1): $1-22$.

Lockwood, Penelope, and Ziva Kunda. 1997. "Superstars and me: Predicting the impact of role models on the self." Journal of personality and social psychology 73 (1): 91.

Margolis, Michele F. 2018. From politics to the pews: How partisanship and the political environment shape religious identity. University of Chicago Press.

McFarland, Daniel A, and Reuben J Thomas. 2006. "Bowling young: How youth voluntary associations influence adult political participation.” American sociological review 71 (3): 401425.

Miller, Carole. 2019. “The GOP's commitment to electing talented women can help party retake the House." The Hill.

URL: $\quad$ https://thehill.com/blogs/congress-blog/politics/444173-the-gops-commitment-toelecting-talented-women-can-help-party

Milyo, Jeffrey, and Samantha Schosberg. 2000. "Gender bias and selection bias in House elections." Public Choice 105 (1-2): 41-59.

Mo, Cecilia Hyunjung, Katharine M Conn, and Georgia Anderson-Nilsson. 2019. "Youth na- 
tional service and women's political ambition: the case of Teach For America." Politics, Groups and Identities.

Moss-Racusin, Corinne A., and Laurie A. Rudman. 2010. “Disruptions in Women's SelfPromotion: The Backlash Avoidance Model.” Psychology of Women Quarterly 34 (2): 186202.

Mummolo, Jonathan, and Erik Peterson. 2019. "Demand effects in survey experiments: An empirical assessment.” American Political Science Review 113 (2): 517-529.

Niemi, Richard G, and M Kent Jennings. 1991. "Issues and Inheritance in the Formation of Party Identification.” American Journal of Political Science 35 (4): 970-988.

O’Brien, Diana Z, and Johanna Rickne. 2016. “Gender quotas and women's political leadership." American Political Science Review 110 (1): 112-126.

Pew Research Center. 2013. A Portrait of Jewish Americans: Findings from a Pew Research Center Survey of U.S. Jews. Technical report Report.

Preece, Jessica, and Olga Stoddard. 2015. "Why women dont run: Experimental evidence on gender differences in political competition aversion." Journal of Economic Behavior \& Organization 117: 296-308.

Preece, Jessica Robinson. 2016. "Mind the gender gap: An experiment on the influence of self-efficacy on political interest." Politics \& Gender 12 (1): 198-217.

Rosenbluth, Frances, Joshua Kalla, and Dawn Teele. 2015. “The Female political career.” In The world bank. Women in Parliaments Global Forum (WIP). http://www. womeninparliaments. org/wp-content/uploads/2015/01/Final_13012015_The-Female-Political-Career. pdf. 
Rudman, Laurie A. 1998. "Self-promotion as a risk factor for women: The costs and benefits of counterstereotypical impression management." Journal of Personality and Social Psychology.

Schlesinger, Joseph A. 1966. Ambition and Politics: Political Careers in the United States. Rand McNally and Co.

Schlozman, Kay Lehman, Sidney Verba, and Henry E Brady. 2012. The unheavenly chorus: Unequal political voice and the broken promise of American democracy. Princeton University Press.

Schneider, Monica C, and Angela L Bos. 2019. “The Application of Social Role Theory to the Study of Gender in Politics.” Political Psychology 40: 173-213.

Schneider, Monica C., Mirya R. Holman, Amanda B. Diekman, and Thomas McAndrew. 2016. "Power, Conflict, and Community: How Gendered Views of Political Power Influence Women's Political Ambition.” Political Psychology 37 (4): 515-531.

Schoon, Ingrid. 2001. "Teenage job aspirations and career attainment in adulthood: A 17year follow-up study of teenagers who aspired to become scientists, health professionals, or engineers.” International Journal of Behavioral Development 25 (2): 124-132.

Schoon, Ingrid, and Samantha Parsons. 2002. "Teenage Aspirations for Future Careers and Occupational Outcomes.” Journal of Vocational Behavior 60 (2): 262 - 288.

Seltzer, Richard A, Jody Newman, and Melissa Voorhees Leighton. 1997. Sex as a political variable: Women as candidates and voters in US elections. Lynne Rienner Publishers.

Shames, Shauna L. 2017a. Out of the running: Why millennials reject political careers and why it matters. NYU Press. 
Shames, Shauna Lani. 2017b. “Intersectionality and Political Ambition.” In Oxford Research Encyclopedia of Politics. Oxford University Press.

Teele, Dawn Langan, Joshua Kalla, and Frances Rosenbluth. 2018. "The Ties That Double Bind: Social Roles and Women's Underrepresentation in Politics." American Political Science Review 112 (3): 525-541.

Thomsen, Danielle M, and Michele L Swers. 2017. "Which women can run? Gender, partisanship, and candidate donor networks." Political Research Quarterly 70 (2): 449-463.

Trice, Ashton D., and Nancy McClellan. 1993. "Do Children's Career Aspirations Predict Adult Occupations? An Answer from a Secondary Analysis of a Longitudinal Study.” Psychological Reports 72 (2): 368-370.

Verba, Sidney, Nancy Burns, and Kay Lehman Schlozman. 1997. "Knowing and caring about politics: Gender and political engagement." The journal of politics 59 (4): 1051-1072.

Whitehead-Bust, Michael. 2010. Current trends in Jewish teen participation with out-of-school activities. Technical report Prepared for Rose Community Foundation.

Wing, Coady, Kosali Simon, and Ricardo A Bello-Gomez. 2018. "Designing difference in difference studies: best practices for public health policy research.” Annual Review of Public Health 39. 


\section{Supplementary Materials for Can the Political Ambition of Young Women Be Increased? Evidence from U.S. High School Students}

\section{Contents}

$\begin{array}{ll}\text { Outcome Measures } & 1\end{array}$

Gender Measure $\quad 2$

Baseline Demographics $\quad 2$

Summary of Response Timing 2

$\begin{array}{ll}\text { Analysis } & 5\end{array}$

Results 6

Respondents with Pre-Treatment Data . . . . . . . . . . . . . . . . . 6

All Respondents . . . . . . . . . . . . . . . . . . . . . . . . . . . 6

First Post-Treatment Survey . . . . . . . . . . . . . . . . . . . . . . 7

Treatment Effect Decay . . . . . . . . . . . . . . . . . . . . . . . . 8

$\begin{array}{ll}\text { Bivariate Results } & 11\end{array}$

Effect on Jewish Identity Items 12

$\begin{array}{ll}\text { Within-Subject Correlations } & 13\end{array}$

Who did participants meet with? 13

$\begin{array}{ll}\text { Text Messages to Program Participants } & 13\end{array}$

First pre-program message . . . . . . . . . . . . . . . . . . . . . . . . . . 13

First post-program message . . . . . . . . . . . . . . . . . . . . . . . 13

Follow-up surveys, for both pre- and post-program participants . . . . . . . . . . . . . . . . 13

$\begin{array}{ll}\text { Pre-Analysis Plan } & 14\end{array}$

\section{Outcome Measures}

These outcome measures were all pre-specified in our pre-analysis plan. On each survey, we ask two questions about political efficacy and three questions about political ambition.

Our efficacy questions are:

- Ordinary citizens can do a lot to influence the government in Washington if they are willing to make the effort.

- It's important to me to let my political representatives know how I feel about the issues. 
Responses range from Strongly Agree to Strongly Disagree using a 7 point scale. We code each question using a -3 to +3 scale. Our outcome measure is an index (referred to as efficacy_index) in which we average together respondents' answers on these two questions.

Our ambition questions are, "How likely is it that, someday, when you're older, you might want to...":

- Work on a political campaign?

- Work for the government?

- Run for political office?

Responses range from Extremely Likely to Extremely Unlikely using a 7 point scale. We code each question using a -3 to +3 scale. Our outcome measure is an index (referred to as ambitions_index) in which we average together respondents' answers on these three questions.

For additional interpretability, we define ambitions_2_binary as 1 if the respondent answered positively on the 7-point likelihood scale and 0 for all other responses.

In addition, we are also interested in just the effect on "Run for political office". In code, we refer to this variable as ambitions_2. For additional interpretability, we define ambitions_2_binary as 1 if the respondent answered positively on the 7-point likelihood scale and 0 for all other responses. Other than this binary measure, all other survey measures were standardized to have mean 0 and standard deviation 1.

We also asked four items related to Jewish identity. Three of the items asked: "To what extent do you feel...":

- A connection to the American Jewish community?

- A connection to the Jewish community where you live?

- A connection to Jewish customs and traditions?

Responses ranged from Not at all (1), A little (2), Somewhat (3), to Very much (4).

The fourth item asked: "Do you agree or disagree with the following statements?... My political beliefs are connected to my Jewish identity." This was coded from Strongly disagree $(-3)$ to Strongly agree $(+3)$ using a 7-point scale.

\section{Gender Measure}

On each of the pre-treatment surveys, we asked individuals their self-identified gender. For the purposes of the analysis, we use individuals first self-reported gender. Overall, we have responses from 435 female participants, 262 male participants, and 11 participants who identify as neither male nor female. In addition, we have data from 208 individuals who only took the post-treatment surveys and therefore for whom we have no self-reported gender data.

\section{Baseline Demographics}

The below tables shows respondents' baseline levels of political ambition and efficacy. For respondents who took multiple baseline surveys, the below tables only includes their first response. This table presents the standardized values on the index and full, unstandardized values on each individual item (coded from -3 to +3 ). The table presented in the main text is a simplified, summary of this table using binary responses. 
Table OA1: Summary of Baseline Ambition and Efficacy Views

\begin{tabular}{|c|c|c|}
\hline Variable & Female Average & Male Average \\
\hline Ambition Index & -0.14 & -0.11 \\
\hline \multicolumn{3}{|l|}{ Ambition Items (coded from -3 to +3 ) } \\
\hline Work on a political campaign & 0.21 & -0.11 \\
\hline Run for political office & -1.02 & -0.66 \\
\hline Work for the government & -0.23 & -0.13 \\
\hline Efficacy Index & 0.11 & -0.29 \\
\hline \multicolumn{3}{|l|}{ Efficacy Items (coded from -3 to +3 ) } \\
\hline Ordinary citizens can do a lot to influence the government in Washington if they are willing to make the effort. & 1.76 & 1.21 \\
\hline It's important to me to let my political representatives know how I feel about the issues. & 2.03 & 1.74 \\
\hline \multicolumn{3}{|l|}{ Jewish Identity Items (coded from +1 to +4$)$} \\
\hline A connection to the American Jewish community. & 3.3 & 3.24 \\
\hline A connection to the Jewish community where you live. & 3.47 & 3.4 \\
\hline A connection to Jewish customs and traditions. & 3.27 & 3.15 \\
\hline My political beliefs are connected to my Jewish identity. (coded from -3 to +3 ) & 0.93 & 0.54 \\
\hline $\mathrm{N}$ & 435 & 262 \\
\hline
\end{tabular}

\section{Summary of Response Timing}

The below table summarizes the response timing, including the date of each session and survey as well as the sample sizes. 
Table OA2: Summary of Data

\begin{tabular}{|c|c|c|c|c|}
\hline Survey Date & Cohort & Sample Size & Percent Female & Post Treatment \\
\hline 2019-01-03 & LTK1 & 130 & 0.592 & 0 \\
\hline 2019-01-18 & LTK1 & 82 & 0.636 & 1 \\
\hline 2019-01-31 & LTK1 & 55 & 0.568 & 1 \\
\hline 2019-02-14 & LTK1 & 26 & 0.526 & 1 \\
\hline 2019-02-28 & LTK1 & 23 & 0.333 & 1 \\
\hline 2019-03-06 & LTK1 & 16 & 0.538 & 1 \\
\hline 2019-04-01 & LTK1 & 6 & 0.500 & 1 \\
\hline 2019-01-03 & LTK2 & 130 & 0.592 & 0 \\
\hline 2019-01-18 & LTK2 & 81 & 0.642 & 0 \\
\hline 2019-01-31 & LTK2 & 119 & 0.613 & 1 \\
\hline 2019-02-14 & LTK2 & 77 & 0.519 & 1 \\
\hline $2019-02-28$ & LTK2 & 45 & 0.595 & 1 \\
\hline 2019-03-06 & LTK2 & 39 & 0.586 & 1 \\
\hline 2019-04-01 & LTK2 & 38 & 0.600 & 1 \\
\hline 2019-01-03 & LTK3 & 99 & 0.586 & 0 \\
\hline 2019-01-18 & LTK3 & 51 & 0.569 & 0 \\
\hline 2019-01-31 & LTK3 & 60 & 0.633 & 0 \\
\hline 2019-02-14 & LTK3 & 94 & 0.636 & 1 \\
\hline $2019-02-28$ & LTK3 & 61 & 0.659 & 1 \\
\hline 2019-03-06 & LTK3 & 42 & 0.613 & 1 \\
\hline 2019-04-01 & LTK3 & 40 & 0.469 & 1 \\
\hline 2019-01-18 & LTK4 & 70 & 0.629 & 0 \\
\hline 2019-01-31 & LTK4 & 35 & 0.686 & $\overline{0}$ \\
\hline $2019-02-14$ & LTK4 & 37 & 0.514 & 0 \\
\hline $2019-02-28$ & LTK4 & 91 & 0.649 & 1 \\
\hline 2019-03-06 & LTK4 & 60 & 0.600 & 1 \\
\hline 2019-04-01 & LTK4 & 42 & 0.704 & 1 \\
\hline 2019-01-31 & LTK5 & 66 & 0.697 & 0 \\
\hline 2019-02-14 & LTK5 & 39 & 0.744 & 0 \\
\hline $2019-02-28$ & LTK5 & 57 & 0.684 & 0 \\
\hline 2019-03-06 & LTK5 & 58 & 0.675 & 1 \\
\hline 2019-04-01 & LTK5 & 37 & 0.679 & 1 \\
\hline 2019-02-14 & LTK6 & 41 & 0.585 & 0 \\
\hline 2019-02-28 & LTK6 & 33 & 0.606 & 0 \\
\hline 2019-03-06 & LTK6 & 21 & 0.429 & 0 \\
\hline 2019-04-01 & LTK6 & 28 & 0.524 & 1 \\
\hline
\end{tabular}


The below plot provides a similar summary of how treatment status changes over time.

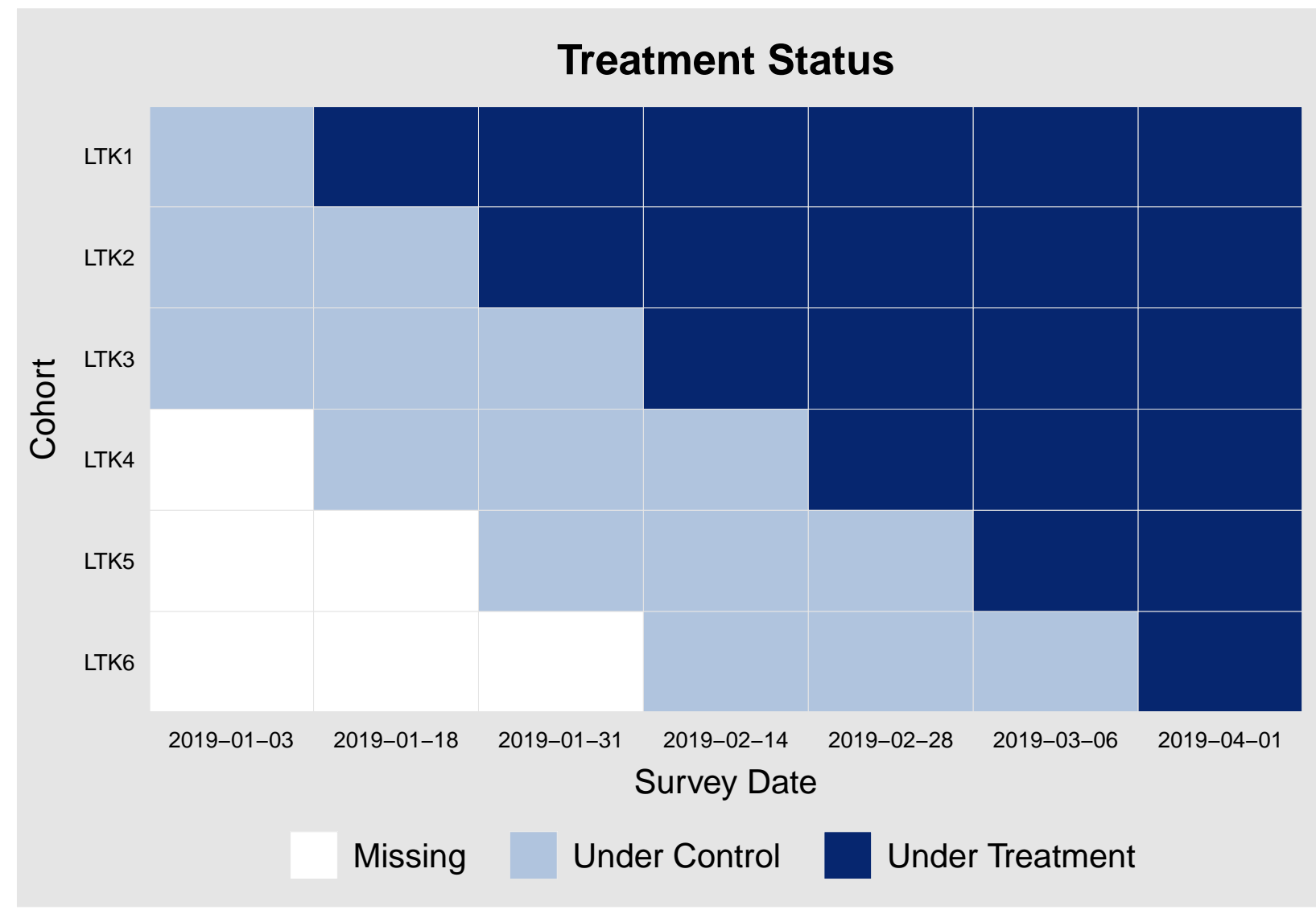




\section{Analysis}

Per our pre-analysis plan, we use the below code for our primary analysis. We deviate slightly from our pre-analysis plan in how $\mathrm{R}$ and Stata treat clustered standard errors in panel data, clustered at the level of the individual respondent. As implemented below, we use the bias-reduced linearization standard errors (Bell and McCaffrey 2002) following code from Pustejovsky (2016). ${ }^{1}$

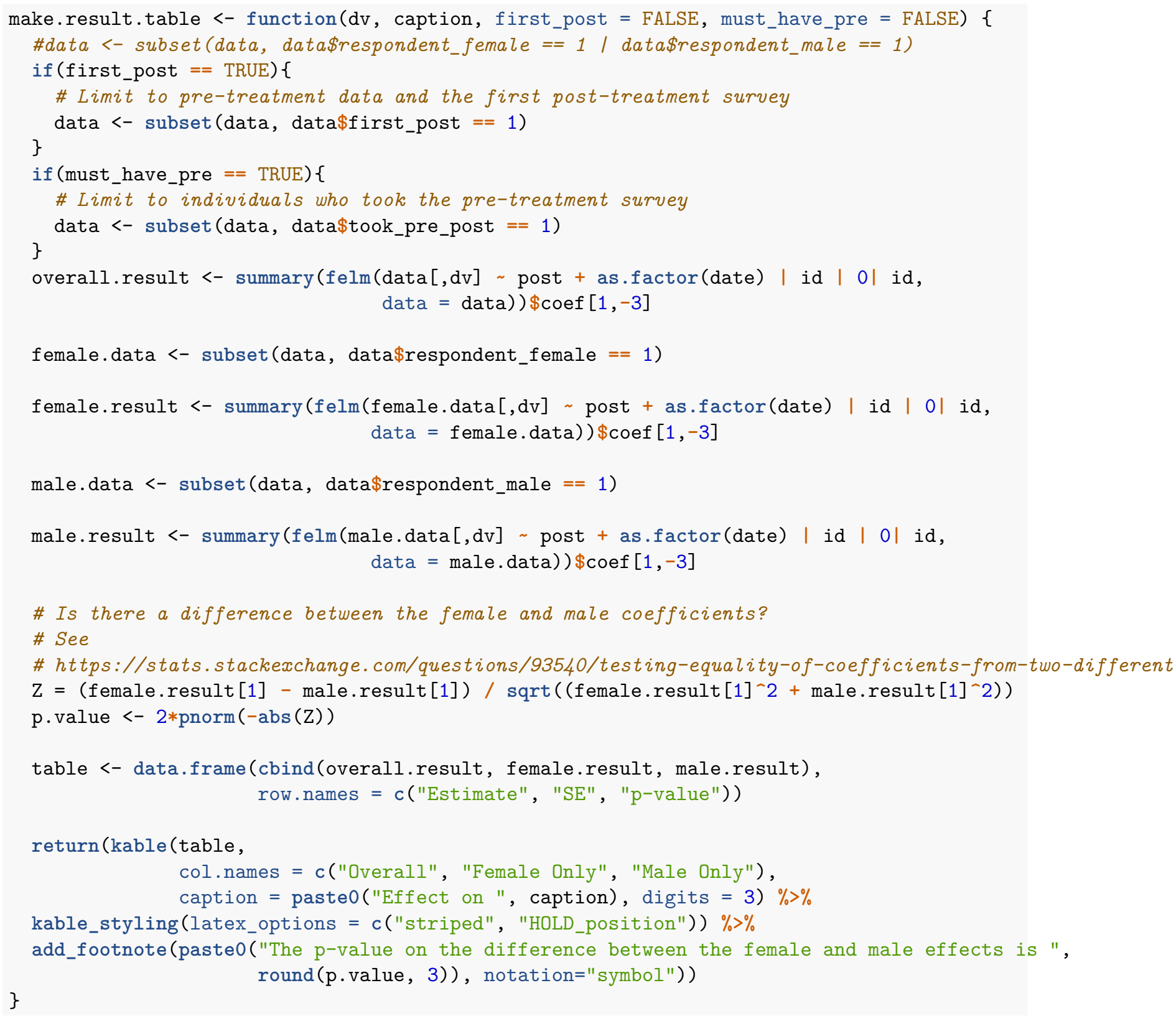

\footnotetext{
${ }^{1}$ See https://www.jepusto.com/clubsandwich-for-crve-fe/
} 


\section{Results}

\section{Respondents with Pre-Treatment Data}

While not specified in our pre-analysis plan, our preferred analysis is to include data only from participants who took at least one pre-treatment survey. This allows us to do the full difference-in-difference analysis. The below tables suggest our results are robust to examining only those individuals who completed at least one pre-treatment survey.

Table OA3: Effect on Ambition Index

\begin{tabular}{l|r|r|r}
\hline & Overall & Female Only & Male Only \\
\hline Estimate & 0.220 & 0.260 & 0.149 \\
\hline SE & 0.047 & 0.065 & 0.067 \\
\hline p-value & 0.000 & 0.000 & 0.028 \\
\hline
\end{tabular}

${ }^{*}$ The p-value on the difference between the female and male effects is 0.712

Table OA4: Effect on Efficacy Index

\begin{tabular}{l|r|r|r}
\hline & Overall & Female Only & Male Only \\
\hline Estimate & 0.265 & 0.214 & 0.310 \\
\hline SE & 0.077 & 0.095 & 0.133 \\
\hline p-value & 0.001 & 0.025 & 0.021 \\
\hline${ }^{*}$ The p-value on the difference between the \\
female and male effects is 0.8
\end{tabular}

Table OA5: Effect on Run for Office

\begin{tabular}{l|r|r|r}
\hline & Overall & Female Only & Male Only \\
\hline Estimate & 0.215 & 0.252 & 0.137 \\
\hline SE & 0.050 & 0.065 & 0.078 \\
\hline p-value & 0.000 & 0.000 & 0.080 \\
\hline
\end{tabular}

${ }^{*}$ The p-value on the difference between the female and male effects is 0.69

Table OA6: Effect on Run for Office: Binary Measure

\begin{tabular}{l|r|r|r}
\hline & Overall & Female Only & Male Only \\
\hline Estimate & 0.097 & 0.112 & 0.067 \\
\hline $\mathrm{SE}$ & 0.028 & 0.037 & 0.043 \\
\hline $\mathrm{p}$-value & 0.001 & 0.003 & 0.119 \\
\hline
\end{tabular}

${ }^{*}$ The p-value on the difference between the

female and male effects is 0.731

\section{All Respondents}

Below we present results across our three main outcomes: the ambition index, the efficacy index, and whether an individual expresses an interest in running for office. Note that the overall results are larger because they 
include both respondents who self-identify as neither male nor female as well as respondents who did not take the pre-treatment surveys and for whom we therefore have no gender data.

Table OA7: Effect on Ambition Index

\begin{tabular}{l|r|r|r}
\hline & Overall & Female Only & Male Only \\
\hline Estimate & 0.221 & 0.229 & 0.161 \\
\hline SE & 0.044 & 0.063 & 0.066 \\
\hline p-value & 0.000 & 0.000 & 0.016 \\
\hline * The p-value on the difference between the \\
female and male effects is 0.806
\end{tabular}

Table OA8: Effect on Efficacy Index

\begin{tabular}{l|r|r|r}
\hline & Overall & Female Only & Male Only \\
\hline Estimate & 0.262 & 0.194 & 0.320 \\
\hline SE & 0.072 & 0.092 & 0.129 \\
\hline p-value & 0.000 & 0.035 & 0.014 \\
\hline
\end{tabular}

${ }^{*}$ The p-value on the difference between the female and male effects is 0.737

Table OA9: Effect on Run for Office

\begin{tabular}{l|r|r|r}
\hline & Overall & Female Only & Male Only \\
\hline Estimate & 0.186 & 0.198 & 0.128 \\
\hline SE & 0.047 & 0.064 & 0.075 \\
\hline p-value & 0.000 & 0.002 & 0.090 \\
\hline
\end{tabular}

${ }^{*}$ The p-value on the difference between the female and male effects is 0.768

Table OA10: Effect on Run for Office: Binary Measure

\begin{tabular}{l|r|r|r}
\hline & Overall & Female Only & Male Only \\
\hline Estimate & 0.087 & 0.093 & 0.062 \\
\hline SE & 0.026 & 0.036 & 0.041 \\
\hline p-value & 0.001 & 0.009 & 0.134 \\
\hline * The p-value on the difference between the \\
female and male effects is 0.783
\end{tabular}

\section{First Post-Treatment Survey}

While not specified in our pre-analysis plan, a second robustness test is to use only the first post-treatment survey data. We may fear that taking the same survey multiple times introduces artificial persistence. The below tables suggest our results are robust to examining only the first survey. 
Table OA11: Effect on Ambition Index

\begin{tabular}{l|r|r|r}
\hline & Overall & Female Only & Male Only \\
\hline Estimate & 0.193 & 0.212 & 0.173 \\
\hline SE & 0.055 & 0.076 & 0.088 \\
\hline p-value & 0.001 & 0.005 & 0.051 \\
\hline${ }^{*}$ The p-value on the difference between the
\end{tabular}

The p-value on the difference between the female and male effects is 0.888

Table OA12: Effect on Efficacy Index

\begin{tabular}{l|r|r|r}
\hline & Overall & Female Only & Male Only \\
\hline Estimate & 0.230 & 0.201 & 0.287 \\
\hline SE & 0.078 & 0.096 & 0.148 \\
\hline p-value & 0.003 & 0.036 & 0.054 \\
\hline
\end{tabular}

${ }^{*}$ The p-value on the difference between the female and male effects is 0.807

Table OA13: Effect on Run for Office

\begin{tabular}{l|r|r|r}
\hline & Overall & Female Only & Male Only \\
\hline Estimate & 0.157 & 0.167 & 0.137 \\
\hline SE & 0.060 & 0.080 & 0.101 \\
\hline p-value & 0.010 & 0.039 & 0.173 \\
\hline${ }^{*}$ The p-value on the difference between the \\
female and male effects is 0.892
\end{tabular}

Table OA14: Effect on Run for Office: Binary Measure

\begin{tabular}{l|r|r|r}
\hline & Overall & Female Only & Male Only \\
\hline Estimate & 0.081 & 0.092 & 0.072 \\
\hline SE & 0.032 & 0.041 & 0.056 \\
\hline p-value & 0.012 & 0.026 & 0.200 \\
\hline *
\end{tabular}

${ }^{*}$ The $\mathrm{p}$-value on the difference between the

female and male effects is 0.861

\section{Treatment Effect Decay}

While not specified in our pre-analysis plan, a reviewer suggested we report treatment effects over time. To do this, we estimate the treatment effect at three time periods among respondents with baseline data: 1-7 days post-treatment (mean of 5.5 days); 8-26 days post-treatment (mean of 18.6 days); and 27-80 days post-treatment (mean of 44.2 days). These date cut-offs were selected to ensure comparable sample sizes during each time period. An important note is that the sample compositions change across the time periods. For example, the March 15 treatment cohort is not included in the longer time periods because they only received one post-treatment survey on April 1.

Below we present the effect on each outcome measure across time periods. 
Table OA15: Effect on Ambition Index

\begin{tabular}{l|r|r|r}
\hline & Estimate & SE & p-value \\
\hline All Data & 0.220 & 0.047 & 0.000 \\
\hline All.Respondents & 0.260 & 0.065 & 0.000 \\
\hline Female & 0.149 & 0.067 & 0.028 \\
\hline Male & 0.257 & 0.059 & 0.000 \\
\hline 1-7 Days Post-Treatment \\
\hline All.Respondents.1 & 0.278 & 0.079 & 0.001 \\
\hline Female.1 & 0.245 & 0.097 & 0.013 \\
\hline Male.1 & 0.158 & 0.087 & 0.070 \\
\hline 8-26 Days Post-Treatment \\
\hline All.Respondents.2 & 0.213 & 0.120 & 0.076 \\
\hline Female.2 & 0.050 & 0.123 & 0.683 \\
\hline Male.2 & 0.280 & 0.102 & 0.006 \\
\hline 27-80 Days Post-Treatment \\
\hline All.Respondents.3 & 0.310 & 0.140 & 0.028 \\
\hline Female.3 Male.3 3 & 0.281 & 0.165 & 0.091 \\
\hline
\end{tabular}

Table OA16: Effect on Efficacy Index

\begin{tabular}{l|r|r|r}
\hline & Estimate & SE & p-value \\
\hline All Data & 0.265 & 0.077 & 0.001 \\
\hline All.Respondents & 0.214 & 0.095 & 0.025 \\
\hline Female & 0.310 & 0.133 & 0.021 \\
\hline Male & 0.242 & 0.094 & 0.010 \\
\hline 1-7 Days Post-Treatment \\
\hline All.Respondents.1 & 0.287 & 0.110 & 0.010 \\
\hline Female.1 & 0.213 & 0.182 & 0.245 \\
\hline Male.1 & 0.059 & 0.196 & 0.765 \\
\hline 8-26 Days Post-Treatment \\
\hline All.Respondents.2 & 0.126 & 0.149 & 0.396 \\
\hline Female.2 & 0.273 & 0.249 & 0.274 \\
\hline Male.2 & 0.002 & 0.197 & 0.992 \\
\hline 27-80 Days Post-Treatment \\
\hline All.Respondents.3 & 0.200 & 0.255 & 0.433 \\
\hline Female.3 3 Male.3 30.302 & 0.311 & 0.334 \\
\hline
\end{tabular}


Table OA17: Effect on Run for Office (scale)

\begin{tabular}{l|r|r|r}
\hline & Estimate & SE & p-value \\
\hline All Data & 0.215 & 0.050 & 0.000 \\
\hline All.Respondents & 0.252 & 0.065 & 0.000 \\
\hline Female & 0.137 & 0.078 & 0.080 \\
\hline Male & 0.252 & 0.065 & 0.000 \\
\hline 1-7 Days Post-Treatment \\
\hline All.Respondents.1 & 0.251 & 0.083 & 0.003 \\
\hline Female.1 & 0.270 & 0.117 & 0.023 \\
\hline Male.1 & 0.244 & 0.101 & 0.016 \\
\hline 8-26 Days Post-Treatment \\
\hline All.Respondents.2 & 0.343 & 0.132 & 0.010 \\
\hline Female.2 & 0.024 & 0.154 & 0.875 \\
\hline Male.2 & 0.232 & 0.114 & 0.043 \\
\hline 27-80 Days Post-Treatment \\
\hline All.Respondents.3 & 0.260 & 0.146 & 0.078 \\
\hline Female.3 & 0.217 & 0.198 & 0.273 \\
\hline Male.3
\end{tabular}

Table OA18: Effect on Run for Office: Binary Measure

\begin{tabular}{l|r|r|r}
\hline & Estimate & SE & p-value \\
\hline All Data & 0.097 & 0.028 & 0.001 \\
\hline All.Respondents & 0.112 & 0.037 & 0.003 \\
\hline Female & 0.067 & 0.043 & 0.119 \\
\hline Male
\end{tabular}

\begin{tabular}{l|r|r|r}
\hline \multicolumn{1}{c}{ 1-7 Days Post-Treatment } \\
\hline All.Respondents.1 & 0.109 & 0.036 & 0.003 \\
\hline Female.1 & 0.104 & 0.047 & 0.029 \\
\hline Male.1 & 0.132 & 0.064 & 0.042 \\
\hline
\end{tabular}

8-26 Days Post-Treatment

\begin{tabular}{|c|c|c|c|}
\hline All.Respondents.2 & 0.104 & 0.049 & 0.034 \\
\hline Female. 2 & 0.134 & 0.066 & 0.043 \\
\hline Male.2 & 0.041 & 0.074 & 0.584 \\
\hline \multicolumn{4}{|c|}{ 27-80 Days Post-Treatment } \\
\hline All.Respondents.3 & 0.025 & 0.067 & 0.712 \\
\hline Female. 3 & 0.018 & 0.091 & 0.841 \\
\hline Male.3 & 0.060 & 0.102 & 0.560 \\
\hline
\end{tabular}

\#\# Warning: Using shapes for an ordinal variable is not advised 


\section{Bivariate Results}

Another way to examine these results is comparing the average value on each outcome measure for both the pre-treatment and post-treatment data.

Table OA19: Effect on Ambition Index

\begin{tabular}{l|r|r}
\hline & Pre & Post \\
\hline Overall & -0.097 & 0.099 \\
\hline Female & -0.090 & 0.082 \\
\hline Male & -0.112 & 0.111 \\
\hline
\end{tabular}

Table OA20: Effect on Efficacy Index

\begin{tabular}{l|r|r}
\hline & Pre & Post \\
\hline Overall & -0.050 & -0.008 \\
\hline Female & 0.085 & 0.140 \\
\hline Male & -0.266 & -0.211 \\
\hline
\end{tabular}

Table OA21: Effect on Run for Office

\begin{tabular}{l|r|r}
\hline & Pre & Post \\
\hline Overall & -0.096 & 0.108 \\
\hline Female & -0.141 & 0.039 \\
\hline Male & -0.018 & 0.200 \\
\hline
\end{tabular}

Table OA22: Effect on Run for Office: Binary

\begin{tabular}{l|r|r}
\hline & Pre & Post \\
\hline Overall & 0.292 & 0.368 \\
\hline Female & 0.249 & 0.319 \\
\hline Male & 0.355 & 0.439 \\
\hline
\end{tabular}




\section{Effect on Jewish Identity Items}

In each survey, we asked four questions related to respondents Jewish identity:

- To what extent do you feel: "A connection to the American Jewish community?" (4 point scale from Not at all; A little; Somewhat; Very much)

- To what extent do you feel: "A connection to the Jewish community where you live?" (4 point scale from Not at all; A little; Somewhat; Very much)

- To what extent do you feel: "A connection to Jewish customs and traditions" (4 point scale from Not at all; A little; Somewhat; Very much)

- Do you agree or disagree with the following statements? "My political beliefs are connected to my Jewish identity." (7 point scale from Strongly disagree; Disagree; Somewhat disagree; Neither agree nor disagree; Somewhat agree; Agree; Strongly agree)

The training repeatedly connected Jewish values to political effectiveness; the different groups competing in the simulation were penalized/rewarded in part based on the extent to which their behavior during the simulation made some kind of Jewish-based appeal. For example, the students who focused on social media were criticized/lauded depending on how much their social media content had some overt Jewish content. Given this explicit connection to Jewish values and politics, we expect to see movement on the fourth question about Jewish identity but not on the first three items, since these items are not about Jewish values and politics. Note that we did not pre-register these expectations.

Table OA23: Effect on A connection to the American Jewish community

\begin{tabular}{l|r|r|r}
\hline & Overall & Female Only & Male Only \\
\hline Estimate & 0.124 & 0.107 & 0.165 \\
\hline SE & 0.079 & 0.094 & 0.141 \\
\hline p-value & 0.115 & 0.258 & 0.243 \\
\hline *
\end{tabular}

The p-value on the difference between the female and male effects is 0.768

Table OA24: Effect on A connection to the Jewish community where you live

\begin{tabular}{l|r|r|r}
\hline & Overall & Female Only & Male Only \\
\hline Estimate & 0.021 & 0.122 & -0.154 \\
\hline $\mathrm{SE}$ & 0.075 & 0.091 & 0.130 \\
\hline p-value & 0.782 & 0.180 & 0.238 \\
\hline
\end{tabular}

${ }^{*}$ The p-value on the difference between the female and male effects is 0.16

Table OA25: Effect on A connection to Jewish customs and traditions

\begin{tabular}{l|r|r|r}
\hline & Overall & Female Only & Male Only \\
\hline Estimate & 0.036 & 0.098 & -0.075 \\
\hline SE & 0.063 & 0.079 & 0.108 \\
\hline p-value & 0.563 & 0.217 & 0.489 \\
\hline${ }^{*}$ The p-value on the difference between the \\
female and male effects is 0.161
\end{tabular}


Table OA26: Effect on My political beliefs are connected to my Jewish identity

\begin{tabular}{l|r|r|r}
\hline & Overall & Female Only & Male Only \\
\hline Estimate & 0.175 & 0.141 & 0.200 \\
\hline SE & 0.071 & 0.080 & 0.138 \\
\hline p-value & 0.015 & 0.080 & 0.150 \\
\hline${ }^{*}$ The p-value on the difference between the \\
female and male effects is 0.81
\end{tabular}

\section{Within-Subject Correlations}

Within the pre-treatment surveys, the ambition index has a correlation of 0.864 across two survey waves and the efficacy index has a correlation of 0.593 .

\section{Who did participants meet with?}

Among the 435 female participants who took a baseline survey, 1.1\% met with at least one female Member of Congress and $89.2 \%$ met with at least one female staffer.

Among the 262 male participants who took a baseline survey, $6.1 \%$ met with at least one male Member of Congress and $88.2 \%$ met with at least one male staffer.

\section{Text Messages to Program Participants}

The following messages were used to invite participants to take the surveys. Cell phone numbers were acquired during the registration phase.

\section{First pre-program message}

"Hey [First name], glad you're coming to DC with your synagogue for the RAC's L'Taken seminar. We need your help-can you take a short survey? If you complete it, you'll be eligible to win a $\$ 50$ Amazon gift card. Thanks! [Link to survey]"

\section{First post-program message}

"Hey [First name], we're interested in learning about your experiences at L'Taken in DC. Can you take this short survey again? If you complete it, you'll be eligible to win a $\$ 50$ Amazon gift card. Thanks! [Link to survey]"

\section{Follow-up surveys, for both pre- and post-program participants}

"Hey [First name], we know you might've already filled out this survey but the RAC needs your help again. If you complete the survey again, you will be re-entered to win a $\$ 50$ Amazon gift card. Thanks! [Link to survey]" 


\section{Pre-Analysis Plan}

On the next page is the pre-analysis plan. 


\section{Pre-Analysis Plan for a Difference-in-Difference Design on Increasing Political Ambition and Efficacy in High School Students}

We are conducting an ongoing difference-in-difference design to measure the efficacy of a high school lobbying program. In this program, high school students from across the country come to Washington, D.C. to lobby their federal elected officials and/or their staffs on a variety of topics relevant to them. Students also receive briefings and participate in trainings on federal policymaking.

We are measuring whether this program can increase the political ambition and feelings of political efficacy among its participants. In particular, we will measure whether this program reduces the gender gap in political ambition.

Our analysis is limited to a difference-in-difference design due to programmatic constraints. The partner organization is unable to implement a randomized experiment. Nonetheless, our analysis will be a differencein-difference design in which we compare the pre- and post-participation attitudes using surveys of participating high school students. We are leveraging the fact that there will be six cohorts of participants spread over January-March 2019 for which we will have multiple pre- and post-surveys, as summarized in the below table (with approximate dates for fielding the surveys):

\begin{tabular}{|l|l|l|l|l|l|l|}
\hline & $\begin{array}{l}\text { Jan 11 } \\
\text { Cohort }\end{array}$ & $\begin{array}{l}\text { Jan 25 } \\
\text { Cohort }\end{array}$ & Feb 8 Cohort & $\begin{array}{l}\text { Feb 25 } \\
\text { Cohort }\end{array}$ & March 1 Cohort & $\begin{array}{l}\text { March 15 } \\
\text { Cohort }\end{array}$ \\
\hline Pre-Survey \#1 & $1 / 3$ & $1 / 3$ & $1 / 3$ & $1 / 18$ & $1 / 28$ & $2 / 15$ \\
\hline Pre-Survey \#2 & $\mathrm{n} / \mathrm{a}$ & $1 / 18$ & $1 / 18$ & $1 / 28$ & $2 / 15$ & $2 / 28$ \\
\hline Pre-Survey \#3 & $\mathrm{n} / \mathrm{a}$ & $\mathrm{n} / \mathrm{a}$ & $1 / 28$ & $2 / 15$ & $2 / 28$ & $3 / 6$ \\
\hline Post-Survey \#1 & $1 / 18$ & $1 / 28$ & $2 / 15$ & $2 / 28$ & $3 / 6$ & $3 / 20$ \\
\hline Post-Survey \#2 & $1 / 28$ & $2 / 15$ & $2 / 28$ & $3 / 6$ & $3 / 20$ & $4 / 1$ \\
\hline Post-Survey \#3 & $2 / 15$ & $2 / 28$ & $3 / 6$ & $3 / 20$ & $4 / 1$ & TBD \\
\hline Post-Survey \#4 & $2 / 28$ & $3 / 6$ & $3 / 20$ & $4 / 1$ & TBD & TBD \\
\hline Post-Survey \#5 & $3 / 6$ & $3 / 20$ & $4 / 1$ & TBD & TBD & TBD \\
\hline Post-Survey \#6 & $3 / 20$ & $4 / 1$ & TBD & TBD & TBD & TBD \\
\hline Post-Survey \#7 & $4 / 1$ & TBD & TBD & TBD & TBD & TBD \\
\hline
\end{tabular}

On each survey, we will ask two questions about political efficacy and three questions about political ambition.

Our efficacy questions are:

- Ordinary citizens can do a lot to influence the government in Washington if they are willing to make the effort.

- It's important to me to let my political representatives know how I feel about the issues. 
Responses range from Strongly Agree to Strongly Disagree using a 7 point scale. We will code each question using a -3 to +3 scale. Our outcome measure will be an index in which we average together respondents' answers on these two questions.

Our ambition questions are, "How likely is it that, someday, when you're older, you might want to...":

- Work on a political campaign?

- Work for the government?

- Run for political office?

Responses range from Extremely Likely to Extremely Unlikely using a 7 point scale. We will code each question using a -3 to +3 scale. Our outcome measure will be an index in which we average together respondents' answers on these three questions.

Our principal hypothesis is that participation in the program will increase political ambition and efficacy.

Our analysis will take the following form:

$$
Y_{i, t}=\gamma_{t}+\tau \omega_{i, t}+\alpha_{i}+\mu_{i, t}
$$

where $Y$ is our outcome measures (efficacy and ambition indices), $\gamma_{t}$ is an indicator for the survey time period, $\omega_{i, t}$ is an indicator for whether individual $i$ participated in the lobbying program before $t$ (such that as soon as an individual participates between $t-1$ and $t$, this indicator is set to 1 and then is then always coded as participated thereafter), $\alpha_{i}$ is an individual-level fixed effect, $\mu_{i, t}$ are the idiosyncratic errors clustered at the individual level, and $\tau$ is the treatment effect of participating that we are estimating. The identification strategy of the differences-in-differences design rests on the fact that we have precise measures of participants' views both before and after they participate.

In addition, because of the large literature on a gender gap in political ambition (which we replicate in our 3 January survey), we will examine whether the program is particularly effective at increasing political ambition among female participants. In addition to the two indices described above, we will also examine effects solely on the "Run for political office" outcome measure since that is a primary outcome in that literature. We will examine whether there is an interaction between post-program political ambition and efficacy with gender. While we will report what we find, we are treating this matter as an open research question, not a directional hypothesis.

Finally, in the first survey immediately following the program, we will ask respondents a free response question on what they learned from the weekend. We will use these responses to these open-ended questions to qualitatively investigate potential mechanisms for any attitude changes.

Note that we are filing this PAP after the 3 January survey but prior to any post-program survey. Thus we are blind to all results at this time. 